\title{
Enclosing the River: Industrialisation and the 'Property Rights' Discourse in the Liri Valley (South of Italy), 1806-1916
}

\section{STEFANIA BARCA}

\section{S.V. Ciriacy Wantrup fellow}

Dept. of Environmental Science, Policy and Management

Division of Society and Environment

University of California at Berkeley

Email: sbarca@nature.berkeley.edu, sbarca@libero.it

\begin{abstract}
The 'tragedy of the commons' narrative states the eco-efficiency of private property, but this is basically a theoretical assumption, nor it is supported by the environmental history of the industrial era. The Liri valley story, located at the periphery of the industrial revolution, provides an excellent opportunity for investigating the environmental impact of privatisation in water resources, and its social costs. The article also shows how, in the process of appropriating the energetic yield of water, early industrial capitalists participated in the emergence of the post-feudal discourse of private property and public good.
\end{abstract}

\section{KEYWORDS}

Water, industrialisation, property rights, southern Italy

\section{REVERSING THE 'TRAGEDY OF THE COMMONS' NARRATIVE}

Almost forty years have passed since the American biologist Garrett Hardin formulated the 'tragedy of the commons' thesis. The author restated the classic Malthusian theory from a marginalist perspective, focusing on the problem of free riding in an open access regime. ${ }^{2}$ The most controversial point in this theory was that the author equated the commons with an open access regime. In fact, most of the common property debate developed in the last three decades starts from this perspective. ${ }^{3}$

What the research has left untested is the assumption that, given a situation of free access to natural resources, the assertion of individual property rights 
is an eco-efficient solution, that is, a means of overcoming the neomalthusian/ marginalist paradox. ${ }^{4}$ It is assumed that in private property regimes individuals bear the costs of the exploitation of nature and as a result they are compelled to act responsibly. ${ }^{5}$ This version of efficiency, as a consequence of an individualised cost/benefit equation, is misleading and has too often proved ecologically disastrous. The logic of Hardin's view is based on the presumption that private property, and the legal system that sustains it, give a proper value to ecological stability and equity in the distribution of environmental costs. Yet the environmental history of capitalist industrialisation, and its environmental impact in the last two centuries, would tend to suggest that the ability of private property to protect the environment is mostly a theoretical assumption. That there has been ecological disruption, stemming from the global incorporation of nature within the capitalist mode of production, cannot be denied, even from the most optimistic point of view.

The existence of socio-ecological costs to the system of private property has been apparent since the initial stages of industrialisation. ${ }^{6}$ However, most historical accounts of common resources in Europe have focused on the pre-industrial age, namely before the market economy increasingly extended its control over the world's natural resources. ${ }^{7}$ This perspective has left unexplored the very incorporation of nature by the capitalistic firm, especially through industrialisation. Although Ted Steinberg's pioneering work on the topic ${ }^{8}$ revealed the potential of this kind of study, the ecological perspective on the history of the capitalistic firm, and the property rights structure that formed its basis, is still largely neglected. If we consider the industrial revolution primarily as a cause of change in the ecological relations of production, and the industrial firm as the subject that controls this change, ${ }^{9}$ then it becomes essential to understand the ecological culture of industrial capitalism, rooted in a new way of interpreting property rights over nature.

The story of industrialisation in the Liri valley challenges some of the basic assumptions in the 'tragedy of the commons' account. In the Liri, privatisation of water resources did occur as a reaction to a previous feudal/communal regime, but it did not produce efficient resource management in either ecological or economic terms. Exclusive property rights were claimed over water, but both the transaction costs and the environmental costs of industrialisation were persistently high throughout the nineteenth century. Explaining this requires the location of the property rights discourse on natural resources in the context of the emergence of individual land-ownership and the spread of the capitalistic firm in Europe. Both were related to the classical liberal theory in its triumphant age. Fitting in this context, the Liri valley case answers some important questions in the debate on common resources, about the extent to which individual choice is embedded in particular historical and cultural situations, and in the social discourse of property. ${ }^{10}$ 
In what follows, I argue that the re-definition of property rights in the Liri valley's waters was grounded in a process of cultural re-elaboration that was intended to construct a new legal framework by which the private appropriation of water was legitimised. In other words, it was a discourse about the redefinition of things (water and property) in a sense favourable to capital. ${ }^{11}$ In this discourse, private property was asserted as a necessary means to economic growth, despite evidence emerging of its failure in energetic and ecological efficiency. The property rights discourse in the Liri valley (as well as the one about the 'tragedy of the commons' today) owed much of its tempo to the embeddedness of actors (and scholars) in historical and cultural situations, rather than to the truth of its assumptions.

Furthermore, in the story of industrialisation in the Liri valley, the availability of the 'wealth of nature', i.e. waterpower, was counterbalanced by the absence of institutions ${ }^{12}$ able to deal with the ecological and social contradictions arising from the liberalisation of water. Conflicts arose among entrepreneurs over the assertion of private and exclusive rights over water, and a State effort to encourage 'mutual coercion' in a common property regime failed. The results of this failure were high transaction costs, and high environmental costs experienced materially through recurrent floods with negative repercussions both on local society and on economic life. Floods were not a long-standing characteristic of the Liri valley: rather they were a byproduct of nineteenth century deforestation (upstream) and industrialisation (downstream), the obverse of economic progress. The costs of environmental disasters in a localised system such as the Liri valley were shared by all social actors: local people, agrarian landowners and mill-owners, all were subject to inundation with subsequent economic losses and health risks.

In the long run, as Hardin observed, free riding brings ruin to all. While Hardin associated free riding with the commons, however, it should more properly be associated with private property: in the Liri valley case, for example, entrepreneurs acted as private owners of the water, imagining it as a natural capital on which they could themselves free-ride. The 'tragedy of the commons', from this perspective, can be seen as a tragedy of water 'enclosure' and privatisation.

\section{WATER, FREEDOM AND THE DISCOURSE OF PROPERTY RIGHTS}

The Liri valley is a small inland area located among mountains between the Apennines and the Tyrrhenian Sea at the border between central and southern Italy. In the early nineteenth century, and until the political unification of the country in 1860, it lay within a northern province of the Kingdom of Two Sicilies (covering the entire South of Italy). Starting around 1800, and despite its geographical marginality, the valley experienced a strong industrialising trend, and 


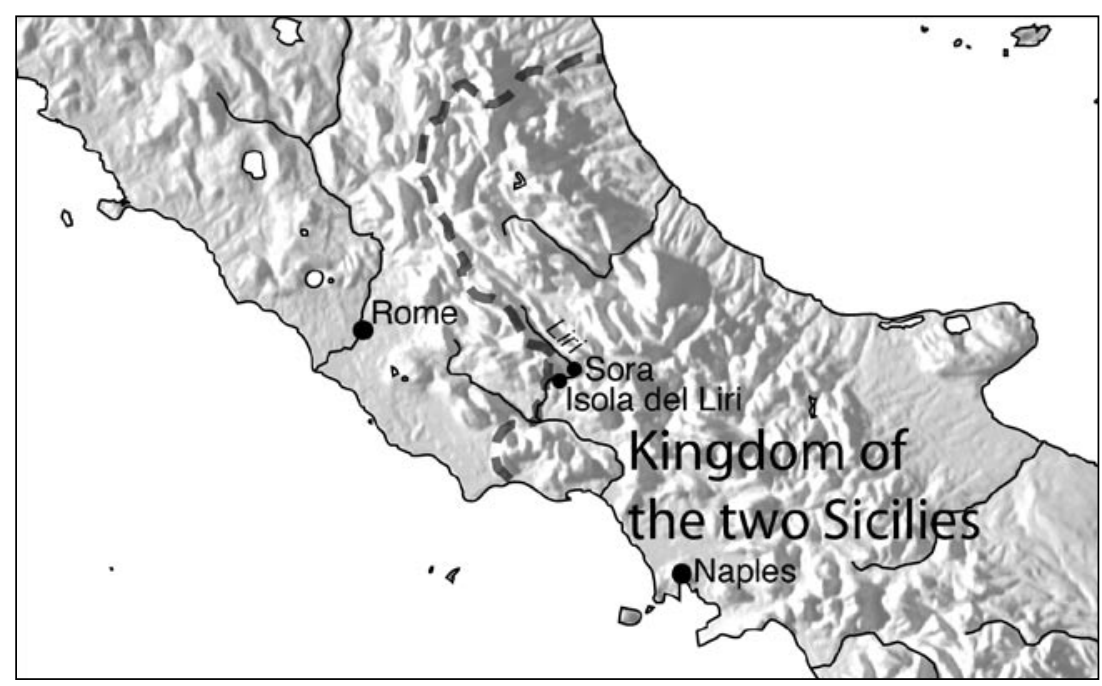

FIGURE 1. Location of the Liri Valley

earned itself a central role in the economy of the Kingdom: after some decades, in the 1840s and 1850s, it had become the industrial core of an agrarian State on the periphery of nineteenth century Europe.

Viewed from a geo-hydrological perspective, the age of industrialisation in the Liri River basin was just a passing moment. Yet, that moment held a disproportionately great value, if we consider the depth of the changes which it carried with it, for both the human beings living in the basin and for the river itself. That shift was not merely a matter of property rights, technology and economic change, it was also a matter of social and ecological re-imagination, one that rendered industrialisation by waterpower possible.

To understand the ecological change that occurred in the Liri valley with industrialisation, we need to understand the way in which the river was reconceived by a new group of social actors emerging in post-feudal Neapolitan society. This was a narrow minority of the wealthy classes in the Kingdom, generally devoted to agrarian and commercial activities, with a strong preference for monopolistic and State-related business. Industrial entrepreneurs had to overcome a highly risky economic environment where internal demand, transportation facilities and minerals were virtually non existent. Historians have suggested that the emergence of industrialisation in this economic environment was an exception related to particular factors, such as the Napoleonic wars, or State intervention, that helped to overcome diseconomies in southern Italy's market structure. ${ }^{13}$

Among these factors, almost no attention has been paid to one of the fatal weaknesses in the local economy, i.e. the cost of energy sources. Italy as a whole 
lacked mineral resources and fossil fuels. The north however, could take advantage of the presence of navigable rivers and relative proximity to European ports enabling the importation of coke. In the southern part of the peninsula there was no such advantage. Thus, the cost of energy sources to industry could have been prohibitive, especially in the inland provinces and far from coastal cities (that is, most of the country). The natural disadvantages in southern Italy's economy explain the reliance of industrialisation on the cheap source of mechanical power produced by rivers. This was the case in the industrial revolution in the Liri valley. Here, the abundance of waterpower was the crucial factor enabling the transformation of a previous putting-out system of wool production into a factory system, filled with water-powered mills located side by side in a narrow stretch of the basin along the towns of Sora and Isola Liri. This took decades to be completed and factories continued to co-exist with home-works for a long time, but the outline economic trajectory was clear and definite as early as the second decade of the nineteenth century. In the 'great transformation' of the Liri valley economy from a system of rural domestic production to an urban industrial one, water acted as a key resource, being the energy source around which the entire factory system was centred.

That said, we still do not have a clear explanation of either ecological or economic change in the Liri valley. There has always been water and the technology to exploit waterpower had not changed substantially. ${ }^{14}$ The transformation of the river into a form of natural capital, conceived as a means of producing profit for individual entrepreneurs and economic progress for the district and the entire nation's economy, was the real change occurring in the first decade of the century. So, at the core of industrialisation in the Liri valley, there lay a shift in the cultural construction of natural resources and the means of putting them to work in the production of a new social order, based on the classical liberal principles of individual interest and free market.

This shift needs to be explained in the context of the political and institutional turbulence in the Kingdom from the end of the eighteenth century. A short Jacobinian revolution and the institution of a republic in 1799, though quickly suppressed, had shown the extent to which the Neapolitan elite were concerned with elaboration and experimentation with liberalism. ${ }^{15}$ The entry of the Napoleonic army in 1806 introduced an even more substantial shift: the remaining feudal characteristics of the Neapolitan law were abolished. By the first decade of the nineteenth century the nation's most valuable natural resources, land and water, had all been 'liberalised'.

What liberalisation meant in economic terms was clear to those who had accumulated enough capital in previous decades to purchase former ecclesiastical, baronial, communal and State lands. What it meant in terms of ecological change, though, was to become evident only some years later, when deforestation and floods became the most serious ecological problems facing the Kingdom. ${ }^{16}$ But what liberalisation ought to mean in the case of water was a much more 
complex issue, one that was not solved during the revolutionary decade nor in the subsequent 45 years of the restored Borbone dynasty, which left unaltered almost all of the French reforms.

To address the issue of liberalisation in the Liri valley, we need to start from a decade before the introduction of the Napoleonic code in 1806. In 1796 the whole duchy of Sora, along with all its water rights, had been sold from the Boncompagni family to the Crown. It was the Town Corporation, however, representing the State at the local level, which managed the water rights, and ran the old fulling-mills, renting them to a group of merchants. The monopoly over waterpower, and so the energy rent of the river, had passed from the feudal power to the Crown, and then to the Town Corporation, from which merchants had to rent the fulling-mills. ${ }^{17}$ The district was still in a pre-capitalist stage, where the use of nature was under the control of a 'moral economy': there was no free access to waterpower. Waters belonged to the community, represented by the Corporation of the Town of Sora, which conceived of water as a means of producing an economic rent to the benefit of the community itself. This state of affairs, however, neither implied energetic efficiency, nor was it free of social conflicts. In practice, the Corporation was strongly influenced in its choices by the lobbying of merchants, the most powerful economic group. ${ }^{18}$ In a few years, however, the situation rapidly changed. The law of 2 August 1806 abolished the feudal regime and the institutional remnants of the "moral economy'. As a consequence, a larger number of individuals gained access to, and exclusive rights on water, while the Corporation lost its control over the river's energetic rent.

This shift was the result of a very complex process, during which a particular discourse of private property emerged. The law of 1806 stated that rivers, once any feudal rights over them were abolished, remained 'publicly owned', and their use regulated according to the Roman Law, which considered them res nullius (no one's thing). The word 'public' at this stage of liberalisation did not mean a State property, but referred to the general public formed by all citizens. The purpose of the law was to abolish monopoly over the use of waters, and to 'free' them from the control of moral corporations such as communities, the State or ecclesiastical orders. The abolition of the feudal and communal monopoly over water also implied that all the hydraulic machines along public rivers (and formerly run by barons, monastic orders, town corporations or the State) would be maintained as private properties, and the same was true of the canals and associated waterworks. In public rivers, the law stated, everyone could make any improvement, after getting a license from the Crown. Such a license would be granted: 'as soon as we recognise that it will benefit the public, and will not damage any private rights'. Water must be available to anyone who would make use of it for 'public benefit', such as moving mills or irrigating fields. The individual interest of land- or mill-owners was identified as the public interest, as a means to achieve the economic progress of the nation. 
That law reflected the interests of a new social group that desired power and wealth from the opening of the rivers. During the French decade (1806-1815) things changed substantially in the economy of water of the Sora district, making an industrial revolution possible. First and foremost, the Boncompagni palace itself, for centuries the seat of feudal power, was split up and given for rent to individual entrepreneurs, along with the rights of using the waterfall running on its side. In 1809, the first wool factory in the district was established, and in a few years the palace's rooms hosted several factories whose water engines were connected to a system of canals running through the basement. The palace became a power station, the symbol of a new era of progress based on the principles of liberal economy, literally taking the place of the ancient regime. In the meantime, cottage industry wool production began to disappear as merchants became industrial entrepreneurs, concentrating production inside water-powered mills. The manufacturing of paper, previously a by-product of wool production, also became a mechanised process with the introduction of a water-powered cylindrical machine from Holland. ${ }^{19}$ The district of Sora became the official site of paper production for the State and delivered paper to the capital's huge publishing industry. In 1845, the town of Isola Liri, with its 8 square miles of mill-sites, had an industrial population of roughly 1,500 people ( 45 per cent of its economically active population), and was called the 'Manchester of the Two Sicilies' ${ }^{20}$ This was the beginning of industrialisation in the Liri valley. A small institutionally favoured social minority gained free access to a crucial energy source, waterpower, and built a new social order: industrial capitalism. ${ }^{21}$

The liberalisation of the water supply was not a peaceful process, either in social or in ecological terms. As in all revolutions, it involved a long run of social conflict, and what eco-marxists call the 'ecological contradictions of capitalism'. ${ }^{22}$ The French, who were aware of the risk of social conflict from their own experience of revolution, quickly formed a special Court, the Feudal Commission, charged with the task of enforcing the law over the many provinces of the Kingdom. Some of the best known lawyers and political reformers of the time were involved in the Commission, which managed the division of former feudal, ecclesiastical and communal lands around the whole of southern Italy. They also had the task of enforcing the Court's resolutions. Most of the decisions of the Commission regarded the land, but a large number of them dealt with conflicts over water. This kind of conflict was far more difficult to adjudicate, because the law only established free access and the abolition of monopolies. In 1809, after three years of competition between barons, communities and individual claimants, the Minister of the Interior, Giuseppe Zurlo, a man deeply involved in the economic reform process, ${ }^{23}$ issued a memorandum restating the basic principles of the law in regards to waters. ${ }^{24}$ This was to remain a landmark in the legal history of water until the end of the Kingdom, in 1860. The memo stated that the use of non-navigable waters (almost all of the rivers in the Kingdom) did not need a license from public authority, and was a 
matter of private rights. As such, it was regulated by the private law concerning the relationships among those that held title to particular waters. The Minister expressly ruled out calling the administrative power into conflicts arising among individual 'owners' of water rights: his intention was to limit the commitment of the State in resolving such conflicts.

In asserting the private nature of water conflicts, however, Zurlo was not as radical as one might think. He recognised the existence of public interests connected to the use of water, such as common use rights, irrigation, or the prevention of floods and other damages caused by waterworks. In these cases, the memo granted town councils 'freedom of issuing rules' for the partitioning of waters among villages and for public safety purposes. These rules were intended to put distribution and inspection powers in the hands of the community. While individually appropriated, the exploitation of waters was to be limited according to rules concerning the needs of the community and environmental stability. The contradiction between the assertion of private property rights over water and the principle of 'freedom of issuing' a common property management was a result of the theoretic contradictions troubling the Neapolitan elite in the transition from the old regime to the new. Freedom and property were the key concepts of the revolution; at the same time, the new regime strongly asserted the importance of its administrative powers ${ }^{25}$ However, the discourse of private property rights was finally to triumph. Given his commitment to the liberal revolution in the Kingdom, the minister felt compelled to use the language of freedom, rather than that of duty. In fact, while leaving 'free' the local powers to make rules, the memo stated: 'But wherever these rules do not exist, the nature of waters does not subject to any limitations those who want to use them'.

The Zurlo Memorandum provoked an explosion of social conflict all over the country over the assertion and enforcement of disputed rights because it encouraged the idea that private property could be claimed on rivers while maintaining their public nature. The minister could not keep public powers out of the conflict as mill-owners sought to claim their private rights before administrative powers. In the space of a few years, the State was inundated with lawsuits concerning water rights. To overcome the problem, the king reverted to the principles of the Zurlo Memorandum, stating that water rights were a matter of public administration, while ordinary courts were to be involved only in conflicts among individuals. This confusing statement, incorporated into a Royal Decree in 1823, was restated three more times, in 1838 (twice) and in 1850. ${ }^{26}$

The problem of an ill-defined water law was clear even to contemporary observers close to the government. The former Minister of Finance, Ludovico Bianchini, wrote in 1857 that:

Since that law [of 1806] did not make any rule (...), a great confusion arose, and was further nourished by the various sentences of the Feudal Commission concerning water rights on various rivers. In several cases the Crown, on demand from some individuals, had given titles to make particular works on some rivers 
(...), but the efficacy of these directions had always been impeded by a great difficulty in defining if the work brought a public benefit, or if it was damaging other people's rights. Hence those stubborn and expensive suits followed before our courts, often judged over erroneous technical advice. ${ }^{27}$

It was only in 1853 , a few years before the end of the dynasty, that the Crown finally claimed all the waters running through the Kingdom as State property. ${ }^{28}$ After half a century practising individual ownership though, things did not quickly or easily change. While private property had been brought to southern Italian rivers by the French revolutionary army, public property had eventually been asserted by a financially exhausted and politically contested dynasty close to collapse. Economic interests, investments in hydraulic works and money spent to purchase water rights and to defend them in courts and on the field, could not be so simply reversed. An entire culture of appropriation over water and of individual exclusive rights had been firmly asserted on the rivers of the Two Sicilies.

\section{'NATURAL CAPITAL', AND ITS COSTS}

As early as in 1810 the Feudal Commission examined a lawsuit issued by the merchants in the district of Sora against the monopoly of the town corporation over waterpower. The judgement outlined that it was permissible for anyone to build new mills on the Liri River and to use water to move their machines. ${ }^{29}$ While in restating the principle of free access to the rivers it reflected the spirit of the law, the judgement did not share the concern that Zurlo himself had expressed about the need for local rules to establish water rights. Economic freedom (the freedom to own and use nature) was felt to be an idea necessary and sufficient to the pursuit of economic progress. Rooted in the contradictions that lay behind the new political order, this abstract thought was connected to a new ecological imagination of water, expressed by the Neapolitan bourgeoisie in the age of its emergence.

The discourse of ownership is clearly stated in the language of the water conflict along the Liri valley throughout the century. It was used by the claimants as well as by government officials and lawyers: there are not such differences in the use of the terms 'property', 'ownership' and even 'possession' among them as to doubt the existence of common cultural and ecological ideas about water. In 1839, for example, a judgment of the Royal Judge in Sora condemned the convent of St. Restituta for allowing its waterworks to disturb the owner of a wool-mill in 'his ownership of the watercourse' downstream. ${ }^{30}$ Some years later, the same mill owner opposed the waterworks built by another industrialist upstream by appealing to his 'ownership and exclusive possession of the waters' in that stretch of the river, according to a concession he had gained from the Crown in $1838 .^{31}$ 
When, some decades later, the Italian State made an attempt to assert public control over the use of rivers in the district, the attorney of a wool manufacturer declared that his client had 'an exclusive right of possession on the Fibreno river [a tributary of the Liri] coming from purchasing bills'. ${ }^{32}$

The language of appropriation was justified by belief in the coincidence between private property, economic freedom and progress, as expressed by the law. This is also testified by a number of cases. Although the De Ciantis Brothers' wool-mill, built in 1831, had overcome the opposition of the town council to its waterworks being 'illegal and damaging public health' (they caused the inundation of a public road and the stagnation of water), this sentence had not been enforced for some years. The reason lay in the opinion expressed in a town council resolution, that the De Ciantis family 'deserve to be encouraged in the enterprise of their factory, which gives a living to many workers indeed'. Afterwards the owners started to enlarge their waterworks, and another industrialist downstream requested the Intendente (Province Governor) to judge the environmental impact of the new works; an engineer from the Corpo di Ponti e Strade (the Corps of Bridges and Roads) was sent to report on public safety. He expressed a very favourable opinion about the De Ciantis waterworks, since they 'being directed to the improvement of their factory, benefit the public in all respects'. The new fence that the mill-owners wanted to build, according to the engineer's report, was 'necessary to the movement of their machines as well as those machines are necessary to the Nation's culture'. ${ }^{33}$

Throughout the century, lawsuits reiterated the ritual celebration and enforcement of individual property rights over water. The language of appropriation, however, was played out in the field as well as in the courts. Often lawsuits followed violent direct action, such as the breaking of dams or illegal construction of waterworks on others' properties. In 1834 the mill-owner Clemente Simoncelli complained of 'attempts, acts of violence and abuses' that his rivals (three other industrialists) had committed against new water engines he had placed along the river. His 'enemies' had also opened a plug and diverted waters upstream of his mill, so that he had brought a suit against them at the court of primary jurisdiction. They had destroyed a fence on his property, stopped three corn-mills, two fulling-mills and the machines in his wool-mill, 'whose soul', Simoncelli wrote, 'is nothing but the water'. Another suit had been brought, but again the following spring one of his rivals 'had armed his workers' and built a wall to keep Simoncelli from taking water through some pipes from another tract of the river. A riot was quelled by the gendarmerie, and another lawsuit followed. In the meantime another of the rivals had called the administrative power to judge against a new mill that Simoncelli had built to continue wool production. Simoncelli thought that the real aim of this action was the one of weakening his business by making him waste money in legal expenses. He had a suit issued against another mill-owner that had built some waterworks inside his property. In the aftermath, he wrote to the Minister of the Interior, a decisive 
intervention of the State was needed, since 'only the arm of the law can restrain such an arrogance'. 34

The transformation of the Liri River into natural capital through the assertion of private property rights (however highly contested) transformed the valley into an industrial district. Nevertheless, in the long run, industrialisation did not give the expected results. At the end of the century, the demographic growth of the two main factory towns in the valley, Sora and Isola Liri, was slow and controversial. Per capita income was persistently low, as well as salaries, and the literacy level. Social mobility was virtually non-existent, and the entire district seemed not to have developed beyond the transition from putting out to the factory system. Local finances were chronically poor, credit was unavailable at the local level, there were no public schools or hospitals in the district, and the hygienic conditions of the two major towns had worsened since the beginning of the century. ${ }^{35}$

The story of economic failure in the Liri industrialisation can be told in many ways. Market obstacles, competition from the British and French wool industry, political unification and the loss of governmental protection in 1860, have all been evoked as reasons for the negative performance of the district in the long run. These stories are concerned with the general economic structure of the national and international market, and with institutional inefficiency at the State level. Nevertheless, another story should be added, and it is concerned with individuals, entrepreneurial behaviour and institutional inconsistency at the local level. This story could be told from the riverbank of the Fibreno, a tributary of the Liri River. Here in 1896, after ninety years of litigation and environmental disruption, all the industrialists were collected by the Prefect, in order to assist two government engineers in filling a report: then, the last chance was lost for the arrangement of a local agreement about the partition of the waters.

A new law, issued in 1884 by the Italian State, had ordered the compilation of a national list of public waters and their uses. Just ten years later, in 1893, the government issued a rule to make the law effective and help government officials in completing the task. The rule, though, simply asked all users to register their water plugs at the local office of the Genio Civile (the Royal Corps of Engineers). Lacking the will to cooperate among individual users, then, the State had no real control over the situation of national waters. This problem concerned also the Liri valley. The attempt by the local Prefect to force the filing of a list of users in the Fibreno River, was immediately opposed by a legal suit issued by some of them against the Prefect himself before the Council of State.

When the two engineers came to the Fibreno riverbanks, they faced two challenges. On the one hand, they had to solve complex measurement problems concerning the water flow for partitioning among the 'owners'. On the other hand, a paper wall was raised by all participants against their effort to issue a rule for the partitioning. In fact, the industrialists presented such a number of documents and legal petitions asserting their respective property rights against 


\section{STEFANIA BARCA}

each other that an agreement was impossible. At the same time, all the users invoked the intervention of administrative power in order to solve the long lasting conflict. Moreover, they sincerely hoped for a technical solution to the problem that could establish exactly how much water everyone was allowed to 'own' on the base of a numeric allocation of property rights. Unfortunately, the measurement of the water flow was a problem for Italian hydraulics for several decades. ${ }^{36}$ No 'technical solution' to the tragedy of private property in the Liri valley was yet available.

Consequently, the language of legal dispute continued to dominate the controversy: the attorneys overwhelmed the engineers. ${ }^{37}$ The dispute among water users of the Fibreno River and the Prefect was to last a couple of decades: indeed, the length of lawsuits was such that it made them the best means of avoiding State interference in local affairs concerning the use of waters. It ended after the First World War, when the new technology of hydroelectricity overcame the old hydraulic machines located along the riverbanks.

The main anthropological feature of water use in the Liri valley remained the preference for private property, despite the fact that there had been a failure in granting efficient use of the resource. The discourse of individual rights, in fact, fits perfectly with the early capitalistic vision of nature as a source of infinite wealth, once put under the realm of property and mixed with capital investments and labour. This story could be narrated in the technical language of neo-institutional economics, evoking the spectre of 'high transaction costs': the uncertainty of property rights, and the lack in institutional efficiency both at the formal and at the informal level, could be the very key terms of this discourse.$^{38}$ However, such a narrative would ignore the question of the ecological failure of the system, instanced by frequent floods occurring from the beginning of industrialisation in the district, and with the effect of increasing the level of uncertainty both in the economic and in the social life. Violent inundations in the town of Sora are recorded in $1825,{ }^{39} 1833,{ }^{40} 1856-1857,{ }^{41} 1879,{ }^{42} 1903,{ }^{43}$ $1906,{ }^{44}$ and $1910 .{ }^{45}$ But 'ordinary' floods recurred every year, from late autumn to early summer, damaging both agriculture and industry. In the flood of December 1845, three of the most important factories (Ciccodicola, Polsinelli and Courrier) were seriously damaged. ${ }^{46}$

Although precise measurements of the flow of the Liri and its main tributary the Fibreno were difficult to make given the state of the hydraulic science at the time, a substantial increase in the flood regime of the basin seems undisputable. The turning point came in the first half of the 1850s. The town council of Sora resolved to draw up an embankment project, and to cover most of the expense, for a total amount of 15,000 ducati: a huge sum, 15 times the annual income of the town. The project was instigated by the engineer Bucci, the director of a paper mill, but was never finished due to the opposition by the De Ciantis brothers, whose wool mill lying on the same tract of river would have lost most of its water flow. The last years of the Kingdom were the most dramatic in terms 
of the environmental instability of the basin. The town council complained that floods and inundations that had once been the consequence of extraordinary rain, had now become an ordinary phenomenon. The riverbed had been filled with sand deposits and hydraulic works, so that the river level was higher than the town. ${ }^{47}$ In this state of permanent near-disaster, the district of Sora appealed, in 1861, for the help of the new Italian State. A year later, with a contribution by the State of 16,000 liras, ${ }^{48}$ and a total amount of 76,000 liras, the works for the Liri embankment began. They were destined to last several decades, and be a continual drain on the public finances. In 1879, for example, the provincial government contributed more than 300,000 liras, and the State contributed a further 25,000 liras.

In the south of Italy, as well as in many areas of the nineteenth-century Mediterranean, floods were a consequence of both the privatisation of natural resources and demographic growth, which encouraged landowners to deforest in order to grow cereals. Deforestation in such mountainous and hilly regions provoked hydro-geological disorder since rainwater was not prevented from inundating valleys and coastal plains with all the violence of spring and autumn torrential floods. This was well known as early as the beginning of the century, as shown by pioneering studies from government officials like Teodoro Monticelli and Carlo Afan de Rivera. ${ }^{49}$ The Liri valley floods fit this picture of environmental tragedy, but they also have a feature of their own. Not only had land been deforested along the Apennines and the Roveto valley a few miles upstream, but the riverbed had been filled with unregulated waterworks and mills downstream, where the towns of Sora and Isola Liri lay. This made floods more frequent and of particular violence compared with the normal river flow.

The situation was made clear in the first official report on the floods in the district of Sora issued in 1812, which asked mill-owners to return the riverbed to its 'natural' state. ${ }^{50}$ After the inundation of Sora in 1825, the new Director of the Corpo di Ponti e Strade, Carlo Afan de Rivera, denounced the town corporation because, 'instead of making any effort to regulate the waters and make them useful for the factories and irrigation', it tolerated the devastation and accepted this local state of affairs. ${ }^{51}$ This summarised the whole story of floods in the district until the second decade of the twentieth century when most of the factories eventually closed. The government, however, lacking the financial resources to implement its own drainage schemes, never pursued enforcement of legal decisions over floods and environmental security. Institutional inefficiency at both central and local level thus seems to characterise the Liri valley story. The unregulated freedom of individual 'owners' over the water brought 'ruin to all'.

The appropriation of river waters was an exercise in power by a rising group of capitalists over other groups and over nature, and it implied an exercise in ecological imagination, ${ }^{52}$ an attempt at creating a new micro-universe around the factory and its water-powered machines. This new world suited 


\section{STEFANIA BARCA}

the economic policies of the State, aimed at increasing the national wealth by creating a manufacturing industry, and received continuous unconditional support from the Crown. This vision was an extension of the Smithian theory of individual/collective interest related to natural resources and reflected in legal reforms and court decisions. A legal river, in other words, was more strongly perceived than the real river.

The process of re-imagination led the Liri river to become a sort of natural capital, in a sense very different from the one that ecological economics today gives the term, stressing the value to collective goods and services of biodiversity and the non-substitutability of natural resources. ${ }^{53}$ The main characteristic of natural capital in the Liri valley was apparent freedom from past human labour. For the early capitalists, it was something freely offered by nature, whose appropriation, as the contemporary observer Karl Marx stated, gave the owner a net advantage over other capitalists located in ecosystems where no waterpower was available. ${ }^{54}$ Marx himself defined this kind of industrialist as the 'owner of the waterfall'. The value of water, within this cultural perception of nature, resided in its appropriation.

In this sense, then, one cannot speak of free access, in the case of the Liri valley, nor in the case of English and North American industrial basins. First of all, waterpower cannot be produced without the possession of machinery, a fixed capital whose property is not, obviously, without costs. Second, machinery cannot be installed on the river-flow without the possession of a piece of land along the riverbank: another form of capital, which implies the existence of private property rights on land. Third, since the production of manufactured goods by the means of waterpower is the most productive way of using the river, other possible uses (fishery, cattle watering, irrigation), given the structure of market incentives, tend to be replaced by waterpower. Consequently, the situation of the river is one of appropriation by a social group (the mill-owners) by means of their possession of some capital able to increase their resource productivity at the expenses of other groups. The appropriation of the river by mill-owners increases the productivity of water, capital and labour invested in it; being a form of rent, though, waterpower also seems to obey the Ricardian law of decreasing returns, because of the improper enclosing of the river. As the number of waterpower users increased, transaction costs increased exponentially, as we have seen in the Simoncelli case. Furthermore, the enclosing of the river in individual properties actually raised the risk of environmental disruption. Most of the tragedy, therefore, comes from a paradox of ecological perception: individuals felt free to act on their enclosed pieces of nature, without seeing them as part of a whole. These individual maximising choices produced a decline in the quantity and quality of natural capital, which in turn affected the sustainability of the economic system. We can consider this as one of the earliest, basic ecological contradictions of capitalism. 


\section{ECOLOGICAL CONTRADICTIONS OF PRIVATE PROPERTY}

What we have here is not, therefore, an open access system, a 'pasture open to all', but a common resource (the river) on which a basic form of exclusion has been established, without issuing any kind of common property regime. As a number of studies on the commons have shown, an important incentive for individuals to cooperate is the clear perception of mutual dependencies ${ }^{55}$ in the relationship among actors and between them and the resource, with a perspective on the common future. The industrialists in the Liri valley did not have such awareness. They did not conceive themselves as a community but as profit-maximising individuals, and acted accordingly.

Another basic contradiction concerns the river itself and the social perception of property rights on it. Flow, movement and interdependency are the key terms of river ecology: without movement and interrelationships with the bio-physical environment around it, the river wouldn't exist. Waterpower itself is produced by the flow of water along (and inside) the mill-engines. It is an energy flow, not a stock. Obviously, the river could be fenced, and water stored in reservoirs, in order to have stable and measurable energy production. This kind of river appropriation, however, led to some kind of control over large tracts of the river by a single appropriator (a private corporation or State agency), a situation that the theory defines as natural monopoly. In this way, water was allowed to flow only at the rate necessary for the production of power to the benefit of the same agent entitled to take advantage of it. Something similar occurred in New England after the incorporation of the Boston Associates. ${ }^{56}$ In that kind of system, not only privatisation, but also domination was required, both over the river and over other players, in order to produce waterpower and economic efficiency.

Neither mill-owners in the Liri valley, however, nor the Neapolitan government, wanted domination. They sincerely believed in the Lockeian notion of economic freedom and national wealth, ${ }^{57}$ and had left behind centuries of social domination in the form of feudal regimes. They imagined (and practised) a free access/individual appropriation framework, in which there was simply not enough space for the production of efficiency, both in economic and in ecological terms. Individual users tried to maximise their share of the energy yield by overusing the resource (obstructing the riverbed with stones and wood fences, or installing engines inside the river) at the expenses of downstream use and the community. Modifications of the stream and the riverbed, in a multi-owned resource, are extremely counterproductive, because they follow very narrow visions of the system, and cause negative feedbacks on the resource productivity and the same players. A classical prisoner's dilemma occurs, therefore, because individual maximising choices means all the players lose.

Local rules, if issued, would have created a sort of common property regime, based on the exclusion of outsiders and on regulated access by insiders. Such 


\section{STEFANIA BARCA}

common property was not unusual over other Italian rivers, where it had a long history in the form of Consorzi Idraulici, namely users associations, not always formalised, which regulated the partition of water among irrigators, mainly in the Po plain. ${ }^{58}$ The case of the Consorzi Idraulici, as well as many cases in which common property on water resources was involved, show how this was a preferred regime also on resources with high market value, such as water for irrigation, whereas the theory would see an incentive for establishing exclusive rights. ${ }^{59}$ Nevertheless, the Consorzi, and other forms of common property on water resources, have generally concerned irrigation rather than waterpower. As regards the latter, we still do not have a general picture of what happened in the European context. In the Anglo-Saxon context, extended to New England, private property along rivers was generally managed in a regime of riparian rights. It generated indeed many conflicts over the assertion of those rights, as well as increasing transaction costs, and led to legislative evolution toward the doctrine of 'most reasonable use'.

The legal historian Carol Rose has suggested that Anglo-American water law substantially contradicted the classical property rights discourse, generally told as a linear story formed of three stages: free access - common property - private property. In the British and the New England experience of industrialisation, she argued, the use of waterpower led to a shift from a clearly defined private property (the 'ancient use' riparian doctrine) to free access/appropriation (the 'occupancy' doctrine), and finally to common property (the 'reasonable use' doctrine).$^{60}$ Both the classical discourse of property and its revision, however, seem to share a problem of definitions. Although it could look like a sort of common property from a legal history perspective (especially if we compare it to the 'prior appropriation' doctrine of the American West), its contemporaries did not perceive 'reasonable use' as such. Rather it was seen as the triumph of a particular kind of appropriation, the industrial corporation, over other kinds of property (individual landowners, small private mills, etc.), in the context of monopolistic control over the resource. That kind of domination, moreover, was justified by the rhetoric of economic development, which claimants shared with each other. This was the story of New England waterpower as told by Ted Steinberg some years ago. ${ }^{61}$

The Liri valley story questions again the way we define the commons and property in general. Apparently, it led to a shift from common property (the Town Corporation management), to free access/appropriation (the law of 1806), and from this to public property (the Royal Decree of 1853). Nevertheless, a shift in cultural perceptions of natural resources was occurring. In the early nineteenth century, the Neapolitan ruling class was beginning to consider the previous regime as a form of monopoly, and to shift toward a free access regime, considering the latter as a form of private property. Furthermore, they gave the term 'public' a very Smithian meaning, considering the collectivity as the sum of individuals, and the public interest as the sum of private business interests. ${ }^{62}$ 
In the context of such interpretation of property, nature and economic development, they refused any kind of regulation or corporate agency. Their discourse over nature and property, neither neutral in social or in ecological terms, was the framework in which they placed a particular set of action, which produced a particular course of economic and ecological events.

By paying attention to property as a discourse, my aim has been to draw also attention to the 'tragedy of the commons' debate as a meta-narrative located in a particular phase of the history of capitalism. ${ }^{63}$ In the last two centuries, capitalism has been a powerful agency (although by no means the only one) of environmental change, but it has been counterbalanced by a growing social perception of the need to preserve resources and limit economic freedoms. A sort of historical-progressive discourse on the ecological costs of capitalism has been raised, then, to justify the economic exploitation of nature in the early phases of industrialisation. It is a discourse about the collective benefits of economic freedom and private property rights over natural resources, even though they can initially lead to environmental degradation, because their impact in the long run will be the one of economic welfare and environmental recovery. The 'tragedy of the commons' discourse fits in this narrative for it legitimises privatisation as the best possible way of managing nature in a capitalist world, assumed as the best possible world. This story is still being told in many textbooks and taught in university courses, celebrating the process of enclosure in eighteenth century Europe as the start of an age of progress, despite its historical and environmental foundation being highly disputed. Such a discourse is not more ecologically and socially neutral than the discourse over water rights was in the Liri valley socio-ecological balance. Both are connected with the changing power relations that capitalism produces over society and over the natural world.

\section{NOTES}

1 'Property rights discourse' is also in the title of Elizabeth Blackmar's chapter 'Appropriating “The Commons": The Tragedy of Property Rights Discourse', in The Politics of Public Space, ed. S. Low and N. Smith (New York: Routledge, 2006). Although at the time I was writing this article I could not have the opportunity of reading Blackmar's, I have been struck by her illustration of how 'history and ideology have intersected to shape understandings of property rights, and with those understandings, the spaces that they govern' (p. 52).

${ }^{2}$ G. Hardin, 'The Tragedy of the Commons', Science, 162 (1968): 1243-8.

${ }^{3}$ See S.V. Ciriacy-Wantrup and R.C. Bishop, "CCommon Property" as a Concept in Natural Resource Policy', Natural Resources Journal 15 (1975) 713-27.

${ }^{4}$ G.Hardin, 'Political Requirements for Preserving our Common Heritage', in Wildlife and America, ed. H.P. Bokaw (Washington, DC: Council of Environmental Quality, 1978); 'The Tragedy of the Unmanaged Commons', in Commons Without Tragedy, ed. 


\section{STEFANIA BARCA}

R.V Andelson (Savage, MD: Barnes and Noble 1991); 'Extensions of "The Tragedy of the Commons"', Science 280 (1998).

${ }^{5}$ See G. Hardin, 'An Operational Analysis of Responsiblity', in Managing the Commons, ed. G. Hardin and J. Baden (San Francisco: W.H. Freeman, 1977). See also Daniel W. Bromley, Environment and Economy: Property Rights and Public Policy (Oxford: Basil Blackwell, 1991).

${ }^{6}$ An important discussion of the concept of social cost in economic theory was given by W. Kapp, The Social Costs of Private Entreprise (Shocken Books: New York 1971 [1950]); for a survey on the ecological critique of 'efficiency' see J. Martinez-Alier, Ecological Economics. Energy, Environment and Society (Oxford: Basil Blackwell, 1987), and J. Martinez-Alier. The Environmentalism of the Poor: A Study of Ecological Conflicts and Valuation (Cheltenham: Edward Elgar, 2003). About the environmental meanings of private property in North America see E.T. Freyfogle, The Land We Share: Private Property and the Common Good, (Washington, DC: Island Press, 2003) and E.T. Freyfogle, Why Conservation is Failing and How it Can Regain Ground (New Haven, CT: Yale University Press 2006).

${ }^{7}$ For a survey of North-Western European studies see The Management of Common Land in North West Europe, c. 1500-1850, ed. M. De Moor, L. Shaw Taylor and P. Warde (Turnhout, Belgium: Brepols 2002). For the Mediterranean area see J.R. McNeill, The Mountains of the Mediterranean World (Cambridge: Cambridge University Press, 2003); some accounts also in Views from the South. Environmental Stories from the Mediterranean World, ed. M. Armiero (Naples: Consiglio Nazionale delle Ricerche, 2006). For the evolution of the commons in the South of Italy, see G. Corona, Demani e individualismo agrario nel regno di Napoli, 1780-1806 (Napoli: Edizioni Scientifiche Italiane 1995).

${ }^{8}$ T. Steinberg Nature Incorporated. Industrialization and the Waters of New England (Cambridge, MA/New York: Cambridge University Press, 1991). From the same author, see also 'An Environmental Perspective on the Origins of Industrialization', Environmental Review 4 (1986): 261-76.

${ }^{9}$ For this definition see S. Barca, 'Entropia. Un nuovo paradigma per la storia economica?', Meridiana. Rivista di Storia e Scienze Sociali 43 (2002): 185-218.

${ }^{10}$ Beyond the New-Institutionalist approach, focused on the theory of rational individual choices, the debate around the commons is now discovering the 'embeddedness' of individuals 'in particular situations that can only be known through investigations into history, political dynamics and social structure, culture and ecology'. See B.J. McCay, 'Emergence of Institutions for the Commons: Contexts, Situations and Events', in The Drama of the Commons (Washington, DC: National Academy Press, 2002), p. 361. For the rhetoric of property in the debate over the commons see C.M. Rose, Property and Persuasion: Essays on the History, Theory and Rhetoric of Ownership (Boulder, CO: Westview Press, 1994).

${ }^{11}$ For the definition of 'discourse' and its implications in the analysis of institutions I basically rely on D. Harvey, Justice, Nature and the Geography of Difference (Cambridge, MA: Blackwell, 1996).

${ }^{12}$ McCay, 'Emergence of Institutions'.

${ }^{13}$ A good, though not recent, depiction of the Neapolitan economic environment in the nineteenth century is in J.A. Davis, Merchants, Monopolists, and Contractors: A Study 
of Economic Activity and Society in Bourbon Naples, 1815-1860, (New York: Arno Press, 1981).

${ }^{14}$ The first innovation for the production of waterpower of some relevance for European industries, the Fourneyron turbine, dates to the 1830s. Late in the century came the Francis (1847) and Pelton (1889) turbines. See P. Mathias and J.A. Davis (eds.), First Industrial Revolutions, (Oxford: Basil Blackwell, 1990), and V. Smil, Energy in World History (Boulder, CO: Westview Press, 1994).

${ }^{15}$ See on the topic G. Imbruglia (ed.), Naples in the Eighteenth Century: The Birth and Death of a Nation State, (Cambridge: Cambridge University Press, 2000). See also Corona, Demani e individualismo agrario.

${ }^{16}$ See for example P. Bevilacqua, Breve storia dell'Italia Meridionale (Roma: Donzelli, 1993) and Id., Tra natura e storia. Ambiente, economie, risorse in Italia (Roma: Donzelli, 1994); such interpretation has been more recently confirmed in J.R. Mc Neill, 'Tragedies of Privatization. Land, Liberty and Environmental Change in Spain and Italy, 1800-1910', in Land, Property and the Environment, J.F. Richards, ed. (Oakland, CA: Institute for Contemporary Studies, 2002).

${ }^{17}$ Archivio di Stato di Caserta (ASC), Intendenza Borbonica (IB), Ponti e strade (PS), 44, 81, s.d. (1807?). Even in the previous feudal regime, however, the Duchies had to face struggles with the merchants for the exercise of their control over water: see A. Viscogliosi, 'I Boncompagni e l'industria', in Trasformazioni industriali nella media valle del Liri in età moderna e contemporanea (Isola del Liri, FR: Rotary 1988). I draw the concept of energy rent from J.C. Debeir, J.P. Deléage and D. Hemery, In the Servitude of Power: Energy and Civilization Through the Ages, (London: Zed Books, 1990).

${ }^{18}$ About the non-coincidence between common property, ecological efficiency and social equity see P.B. Baumann, 'Historical Evidence on the Incidence and Role of Common Property Regimes in the Indian Himalayas', Environment and History 3 (1997): 323-42

${ }^{19}$ A. Dell'Orefice, 'L'industria della carta nel XIX secolo', in Trasformazioni industriali, op. cit., p. 118.

${ }^{20}$ S. De Majo, L'industria protetta. Lanifici e cotonifici in Campania nell'Ottocento (Naples: Athena 1990).

${ }^{21}$ On free access as a reaction to a previous stage of common property, that favoured a social group against others, see B. McCay and J. Acheson, 'Human Ecology of the Commons', in The Question of the Commons, ed. B. McCay and J. Acheson (Tucson: University of Arizona Press, 1987), 1-34; see also L. Taylor, “"The river would run red with blood". Community and Common Property in an Irish Fishing Settlement', The Question of the Commons, 290-307.

${ }^{22}$ See J. O'Connor, Natural Causes. Essays in Ecological Marxism (New York: Guilford 1998).

${ }^{23}$ P. Villani, Giuseppe Zurlo e la crisi dell'antico regime nel regno di Napoli (Rome 1955).

${ }^{24}$ F. Dias, Legislazione positiva del Regno delle Due Sicilie dal 1806 a tutto il 1840 (Napoli 1841).

${ }^{25}$ A. Spagnoletti, Storia del regno delle due Sicilie (Bologna: Il Mulino 2000).

${ }^{26}$ Dias, Legislazione Positiva.

${ }^{27}$ L. Bianchini, Storia delle finanze del Regno delle due Sicilie (Napoli 1971), 495-6. 


\section{STEFANIA BARCA}

${ }^{28}$ R. Trifone, Feudi e demani. Eversione della feudalità nelle province meridionali (Milano 1909).

${ }^{29}$ Archivio di Stato di Napoli (ASN), Bollettino delle sentenze della Commissione Feudale, vol. 2, p.611.

${ }^{30}$ ASC, IB, Contenzioso Amministrativo, LXXI.

${ }^{31}$ ASC, Prefettura Carte Amministrative, 2, 2180.

${ }^{32}$ ASC, Prefettura Prima serie, cat. XXII, 233, 2467.

${ }^{33} \mathrm{ASN}$, Ministero dell'Interno (MI) $2^{\circ}$ inv., 3102, 10.

${ }^{34}$ ASN, Ministero dell'Interno (MI) $2^{\circ}$ inv., 3102, $6 .$.

${ }^{35}$ See A. Dewerpe, Crescita e ristagno protoindustriali nell'Italia meridionale: la Valle del Liri, in La società inafferrabile, ed. A. De Clementi (Rome: Editori Riuniti 1986); see also S. De Majo, L'industria protetta, cit. and Economia e società in valle del Liri nel secolo XIX. L'industria laniera, ed. C. Cimmino (Caserta 1986).

${ }^{36}$ See S. Barca, 'Running Italian Waters. Hydraulics and Water Law in the Age of Industrialization', in Views from the South, op. cit.

${ }^{37}$ ASC, Prefettura Prima Serie, cat. XXII, 233, 2467.

${ }^{38}$ A classical presentation of this approach is D. North, Institutions, Institutional Change, and Economic Performance (Cambridge: Cambridge University Press, 1990).

${ }^{39}$ ASN, MI, $2^{\circ}$ Inv., 530 and ASC, IB, Affari comunali, 15.

${ }^{40}$ ASN, MI, Consigli Provinciali in Terra di Lavoro, 4054.

${ }^{41}$ ASC IB, Ponti e strade (bonifiche), 44, 183.

${ }^{42}$ ASC, Prefettura Prima Serie, 188, 2105.

${ }^{43}$ ASC, Prefettura Prima Serie, cat. XXII, 253, 2547.

${ }^{44}$ ASC, Prefettura Prima Serie, cat. XXII, 188, 2463

${ }^{45}$ ASC, Prefettura Prima Serie, cat. XXII, 253, 2547.

${ }^{46}$ ASC IB, Ponti e strade (bonifiche), 44, 183.

${ }^{47}$ Ibid.

${ }^{48}$ According to ISTAT, Il valore della lira (Roma, 1996), the Italian lira in 1861 equalled about 6,344 liras at 1995 value (about 3 euros at current value).

${ }^{49} \mathrm{C}$. Afan de Rivera, Considerazioni su i mezzi da restituire il valore proprio a' doni che ha la natura largamente conceduto al regno delle due Sicilie, (Napoli: Dalla stamperia e cartiera del Fibreno, 1832), and T. Monticelli, Memoria sull'economia delle acque da ristabilirsi nel regno di Napoli, (Napoli: Stamperia Reale, 1809). For debate between the two authors regarding the relationship between public and private drainage and reclamation schemes, see also C. D'Elia, Bonifiche e Stato nel regno di Napoli (Napoli: ESI 1994).

${ }^{50}$ ASN, MI, $2^{\circ}$ Inv., 530 and ASC, IB, Affari comunali, 2356.

${ }^{51} \mathrm{ASN}, \mathrm{MI}, 2^{\circ}$ Inv., 530.

${ }^{52}$ Here I draw from Donald Worster's works; see, in particular, The Wealth of Nature: Environmental History and the Ecological Imagination (New York: Oxford University Press, 1993).

${ }^{53}$ Despite some discussion over the correctness of the expression 'natural capital', the literature on ecological economics and sustainability generally share this comprehensive 
and collective way of considering natural resources. For an early definition see D. Pearce, 'Economics, Equity and Sustainable Development', Futures 20 (1988). For a review of the debate see, for example, Martinez Alier, The Environmentalism of the Poor.

${ }^{54}$ See Il Capitale, vol. III (Roma: Editori Riuniti 1994), pp. 741-50.

${ }^{55}$ See in particular E. Ostrom, 'Coping with Asymmetries in the Commons: Self-Governing Irrigation Systems Can Work', Journal of Economic Perspectives, 4 (1993).

${ }^{56}$ Steinberg, Nature Incorporated.

${ }^{57}$ On the topic see Rose, Property and Persuasion.

${ }^{58}$ See P. Bevilacqua, 'Le rivoluzioni dell'acqua', in Storia dell'agricoltura italiana in età contemporanea., ed. P. Bevilacqua (Venezia: Marsilio 1989); F. Cazzola, Storia delle campagne padane dall'Ottocento a oggi (Milano: Angeli 1996); G. Bigatti, La provincia delle acque. Ambiente, istituzioni e tecnici in Lombardia tra Sette e Ottocento (Milano: Angeli 1995); S.Ciriacono, Building on Water: Venice, Holland, and the Construction of the European Landscape in Early Modern Times (New York: Berghahn Books, 2006); A. Prosperi, Il Padule di Fucecchio: la lunga storia di un ambiente "naturale" (Roma: Ed. di Storia e Letteratura, 1995).

${ }^{59}$ See for example E. Ostrom, Crafting Institutions for Self-Governing Irrigation Systems (San Francisco, CA: ICS Press, 1992); for an historical example of common property over water in the Mediterranean see D. Guillet, 'Co-Management of Natural Resources: The Long View from Northwestern Spain', Environment and History 8 (2002): 217-36

${ }^{60}$ See Property and Persuasion, cit.

${ }^{61}$ Nature Incorporated, cit.

${ }^{62}$ About the reception of Adam Smith and British economic thought in the Kingdom of the Two Sicilies, see B. Salvemini, Economia politica e arretratezza meridionale nell'eta del Risorgimento: Luca de Samuele Cagnazzi e la diffusione dello smithianesimo nel Regno di Napoli (Lecce: Milella 1981).

${ }^{63}$ On historical relativism related to the study of nature see Donald Worster, 'Nature and the Disorder of History', in Reinventing Nature? Responses to Postmodern Deconstruction, ed. M.E. Soulé and G. Lease (Washington, DC/Covelo, CA: Island Press 1995), 65-86. For a critical analysis of the 'commons' narrative see also Baumann, 'Historical Evidence', and Blackmar, 'Appropriating "The Commons". 